\title{
A combined radioimmunoassay and immunocytochemical study of ovarian oxytocin production during the periovulatory period in the ewe
}

\author{
D. C. Wathes, S. E. F. Guldenaar, R. W. Swann, R. Webb*, D. G. Porter and \\ B. T. Pickering
}

Department of Anatomy, The Medical School, Bristol BS8 1TD, and *A.F.R.C. Animal Breeding Research Organisation, Dryden Laboratory, Roslin, Midlothian, EH25 9PS, U.K.

\begin{abstract}
Summary. Corpora lutea and follicles were taken from the ovaries of 12 ewes at intervals from the start of luteolysis until 3 days after ovulation. RIA analysis of the tissue oxytocin content showed that luteal oxytocin concentrations declined during luteolysis to reach basal values at about the time of the next ovulation. Oxytocin was first measurable in the walls of 3 out of 6 preovulatory follicles during the LH surge, with a small increase in concentration to $26 \cdot 1+6.6 \mathrm{pg} / \mathrm{mg}$ before ovulation, and a further increase in the young corpus luteum to concentrations exceeding $1 \mathrm{ng} / \mathrm{mg} \mathrm{2-3}$ days later. After the LH surge, oxytocin was also found in the follicular fluid at a concentration of $3.4 \pm 0.3 \mathrm{ng} / \mathrm{ml}$. Using immunocytochemical techniques, oxytocin and neurophysin were first detected in the follicle wall immediately before ovulation, and were localized in the granulosa cells. After ovulation the stained cells initially formed strands which appeared to break down to clusters and then to individual cells as the corpus luteum matured. The immunocytochemical picture also sugested that neurophysin immunoreactivity increased within a few hours of ovulation but that processing to oxytocin may be delayed. Measurements of circulating oxytocin concentrations revealed a pulsatile release pattern throughout the follicular phase with the height of the pulses decreasing from $25 \pm 5 \mathrm{pg} / \mathrm{ml}$ during luteolysis to a minimum of $11 \pm 2 \mathrm{pg} / \mathrm{ml}$ during the $\mathrm{LH}$ surge.
\end{abstract}

\section{Introduction}

The corpora lutea of ewes and cows contain high concentrations of oxytocin (Wathes \& Swann, 1982; Wathes, Swann, Birkett, Porter \& Pickering, 1983) which is localized within the large luteal cells (Watkins, 1983; Guldenaar, Wathes \& Pickering, 1984). There is now direct evidence that the hormone is synthesized locally because the luteal cells of cows and sheep can incorporate $\left[{ }^{35}\right.$ S $]$ cysteine into the oxytocin molecule in vitro (Swann et al., 1984) and Ivell \& Richter (1984) have shown that the oxytocin gene is highly expressed in bovine corpora lutea and has a nucleotide sequence identical to that in the hypothalamus.

Circulating concentrations of oxytocin during the oestrous cycle increase to a maximum during the first part of the luteal phase and fall during luteolysis to reach basal levels around the time of oestrus (Sheldrick \& Flint, 1981; Webb, Mitchell, Falconer \& Robinson, 1981; Mitchell, Kraemer, Brennecke \& Webb, 1982; Schams, Lahlou-Kassi \& Glatzel, 1982; Schams, 1983). However, there is a considerable discrepancy amongst reports over the actual concentration of oxytocin in plasma during the follicular phase in the ewe. The source of any oxytocin circulating at this time is not clear; Mitchell et al. (1982) proposed that pulses of pituitary origin were superimposed on a background secretion from the ovary, but follicular concentrations of oxytocin are extremely low (Flint \& Sheldrick, 1983; Wathes, Swann \& Pickering, 1984). 
Luteal oxytocin is thought to play a role in luteolysis as exogenous oxytocin is luteolytic in cows (Armstrong \& Hansel, 1959) and both active and passive immunization against oxytocin leads to an increase in oestrous cycle length in the ewe (Sheldrick, Mitchell \& Flint, 1980; Schams, Prokopp \& Barth, 1983). Until now most detailed studies have focused on oxytocin release during luteal regression and have shown that oxytocin and its associated neurophysin are released in pulses at this time, with the majority of pulses coinciding with episodes of PGF-2 $\alpha$ release (Fairclough $e t$ al., 1980; Flint \& Sheldrick, 1983; Fairclough, Moore, Peterson \& Watkins, 1984). Luteal oxytocin concentrations have also been shown to decline about 2 weeks after oestrus in ewes in which the lifespan of the corpus luteum is maintained by pregnancy or hysterectomy (Sheldrick \& Flint, $1983 \mathrm{a}, \mathrm{b}$ ). This has led to the suggestion that the control of luteal oxytocin production and secretion may be important for the establishment of pregnancy.

At present little is known about the way in which ovarian oxytocin synthesis is controlled. In the present study we wished to correlate ovarian and peripheral oxytocin concentrations during the follicular and early luteal phases of the cycle with changes in the secretion patterns of other reproductive hormones. The aim was to pinpoint the time at which ovarian oxytocin production was initiated and to identify the cells involved. We hoped that this information would provide insight into the factors controlling ovarian oxytocin synthesis in the ewe.

\section{Materials and Methods}

\section{Animals and treatments}

Twelve 4-6-year-old Clun ewes were synchronized for oestrus using progestagen-impregnated vaginal sponges (Upjohn Ltd, Crawley, West Sussex, U.K.) inserted for 11 days. There were 2 groups, each of 6 ewes. After removal of the sponges the ewes were checked for oestrus with a vasectomized ram. From Day 12 of the following cycle they were housed under conditions of natural lighting and fed hay and water. On Day 14 the jugular vein was cannulated and a blood sample was collected. From Day 15, 20-ml blood samples were collected every $2 \mathrm{~h}$ from Group 1 and every $3 \mathrm{~h}$ from Group 2. The ewes were penned next to the ram and were checked for signs of oestrus every 2-3 h. Animals thought to be in oestrus were placed in with the ram for confirmation. The blood was collected into heparinized tubes on ice and centrifuged at $1000 \mathrm{~g}$ at room temperature for 15 min within 45 min of withdrawal. The plasma was split into 4 separate samples for RIA. That for oxytocin assay $(\sim 5 \mathrm{ml})$ was acidified with $250 \mu \mathrm{l} 0 \cdot 1 \mathrm{M}-\mathrm{HCl}$. All samples were snap frozen on solid $\mathrm{Co}_{2}$ and stored at $-80^{\circ} \mathrm{C}$.

The ovaries were removed at autopsy following an overdose of pentobarbitone sodium i.v. (Euthatal: May \& Baker Ltd, Dagenham, U.K.). One animal was in the late luteal phase, and the other 11 were killed at intervals from the onset of oestrus until $96 \mathrm{~h}$ later. All follicles $>5 \mathrm{~mm}$ in diameter, newly formed corpora lutea, and at least one of the regressing corpora lutea from the previous cycle were dissected out. Follicular fluid was aspirated with a syringe and frozen on solid $\mathrm{CO}_{2}$. All tissue samples were cut into three equal portions. These were: (a) frozen on solid $\mathrm{CO}_{2}$ and stored at $-80^{\circ} \mathrm{C}$ for estimation of tissue oxytocin and vasopressin content; (b) placed in fixative at $4^{\circ} \mathrm{C}$ for immunocytochemistry; and (c) frozen in liquid nitrogen for cDNA probe analysis (to be described in a separate paper). The entire procedure was completed as rapidly as possible (within 10 min of death) to maintain maximum tissue preservation. This meant that samples of follicle wall, and to a lesser extent the newly formed corpora lutea, also contained some stromal tissue.

\section{Radioimmunoassays}

Oxytocin in plasma and follicular fluid. The majority of plasma samples ranged from 4 to $6 \mathrm{ml}$ in volume, although a smaller amount was sometimes collected. Follicular fluid volumes ranged from 





20 to $120 \mu$ l. $\left[{ }^{3} \mathrm{H}\right]$ Oxytocin $(0 \cdot 55-1 \cdot 1 \mathrm{TBq}$, Amersham International, Amersham, U.K.; $50 \mu \mathrm{l}$ in $0.01 \mathrm{M}-\mathrm{HCl}$ containing $\sim 1000$ c.p.m.) was added to each sample which was then passed slowly through a Sep-Pak (Waters Associates Ltd, Milford, MA, U.S.A.) which had been previously treated with $10 \mathrm{ml} 80 \%$ acetonitrile (Koch-Light, Haverhill, Suffolk, U.K.) in $0.1 \%$ trifluoroacetic acid (Rathburn Chemicals Ltd, Walkerburn, U.K.) and $20 \mathrm{ml}$ water. The Sep-Pak was washed with $25 \mathrm{ml} 0 \cdot 1 \%$ trifluoroacetic acid and the extract was eluted with $3 \mathrm{ml} 80 \%$ acetonitrile in $0.1 \%$ trifluoroacetic acid. The acetonitrile was removed under a stream of nitrogen and the remaining extract was freeze-dried. The extract was redissolved in $500 \mu \mathrm{l}$ oxytocin assay buffer $(0.1 \mathrm{M}$ phosphate buffer $\mathrm{pH} 7.4$ ) and centrifuged at $3000 \mathrm{~g}$ at $4^{\circ} \mathrm{C}$ for $20 \mathrm{~min}$ to remove sediment. Two $100 \mu \mathrm{l}$ samples of the supernatant were used for oxytocin RIA and the ${ }^{3} \mathrm{H}$ content of $50 \mu \mathrm{l}$ was counted to estimate the recovery percentage. Blank extracts using the same procedure, but omitting the plasma, were run in each essay. Oxytocin values were corrected for these blank values, which averaged $3.6 \pm 0.45 \mathrm{pg}$ per tube, and for recoveries. The RIA was performed as described by Wathes et al. (1983). See Table 1 for further details.

Oxytocin in tissue. Each sample was partly thawed and weighed. Extraction medium $(3 \mathrm{ml} 15 \%$ trifluoroacetic acid in $1 \mathrm{M}$-formic acid at $\left.4^{\circ} \mathrm{C}\right)$ and $50 \mu \mathrm{l}\left[{ }^{3} \mathrm{H}\right]$ oxytocin were added and the samples were homogenized in a hand-operated glass homogenizer. They were boiled for $5 \mathrm{~min}$ in a water bath and centrifuged at $25000 \mathrm{~g}$ for $30 \mathrm{~min}$ at $4^{\circ} \mathrm{C}$. The supernatant was removed and freeze-dried. The extract was redissolved in $700 \mu \mathrm{l}$ oxytocin assay buffer and assayed as described for oxytocin except that a different antiserum was used; $200 \mu \mathrm{l}$ was also used for measurement of arginine vasopressin.

Arginine vasopressin. RIAs of tissue extracts were performed as described by Wathes et al. (1983). See Table 1 for further details.

Progesterone. The method was based on that described by Wathes \& Porter (1982) using $0.4 \mathrm{ml}$ plasma extracted with $2 \mathrm{ml}$ petroleum ether in duplicate for each sample. See Table 1 for further details.

LH and FSH. The assays were performed as described by Webb, Baxter, Preece, Land \& Springbett (1985). See Table 1 for further details.

\section{Immunocytochemistry}

Pieces of follicle wall or CL (not greater than $3 \mathrm{~mm}$ cubes) were fixed by immersion in $2.5 \%$ glutaraldehyde (BDH Chemicals Ltd, Poole, U.K.) and 4.0\% paraformaldehyde (BDH Chemicals Ltd) in $0.1 \mathrm{M}$-sodium cacodylate buffer (BDH Chemicals Ltd) at $\mathrm{pH} 7.4$ for $6-7$ days at $4^{\circ} \mathrm{C}$. They were then embedded in Paraplast (Oxford Laboratories International Corp., Athy, Co. Kildare, Ireland) and $8 \mu \mathrm{m}$ sections were cut and stained using the peroxidase-antiperoxidase (PAP) technique (Sternberger, 1979). The sections were incubated with the first antiserum for $1 \mathrm{~h}$ at room temperature followed by overnight incubation at $4^{\circ} \mathrm{C}$. The antisera used were: (a) rabbit antioxytocin (RI-5, 1:100, kind gift of Dr I. C. A. F. Robinson, National Institute of Medical Research, Mill Hill, U.K.); (b) rabbit anti-vasopressin (84/2-5, 1:100); and (c) rabbit anti-rat neurophysin $(83 / 7-3,1: 100)$. Controls for the immunocytochemical procedure included the omission of the first antiserum and substitution of the first antiserum by pre-immune rabbit serum $(84 / 2-0$, $1: 100$ ). Sections were dehydrated in graded ethanol and embedded in DePeX. Details of the specificity of the antisera have been described previously (Guldenaar et al., 1984). Additional sections were stained with haematoxylin and eosin.

\section{Follicle classification}

Follicles werejudged to be preovulatory or non-ovulatory based on their size, external appearance 

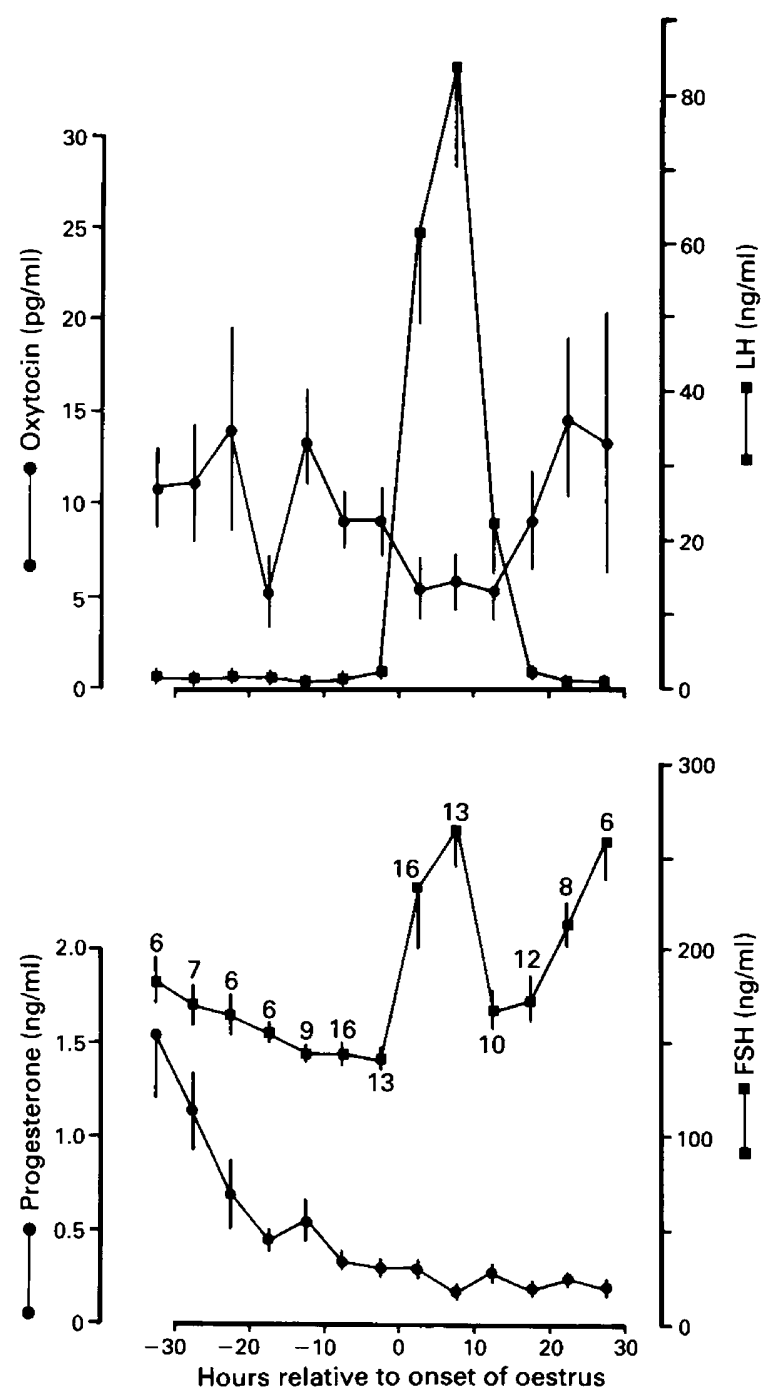

Fig. 1. Hormone profile of the periovulatory period. Values are from 11 ewes sampled at 2 or $3 \mathrm{~h}$ intervals and the mean value \pm s.e.m. for each 5-h period relative to the onset.of the $\mathrm{LH}$ surge is shown. The number of blood samples per estimate is given above the FSH data. Ovulation in this group of animals occurred about $25 \mathrm{~h}$ after the start of the LH surge.

and histology (Hay, Cran \& Moor, 1976; England, Dahmer \& Webb, 1981). Briefly, preovulatory follicles have a translucent appearance and extensive vascularization. The granulosa contains 5-15 layers of healthy, closely apposed cells resting on a distinct basement membrane. About $12 \mathrm{~h}$ before ovulation the junctions between the granulosa cells become disrupted and the basement membrane starts to break down.

\section{Statistical analysis}

All measurements of hormone concentrations were subjected to a square root transformation 
before analysis to produce a normally-distributed variate. The experimental design was unbalanced for the factors time and animal and the transformed measurements were analysed by regression analysis using GENSTAT.

\section{Results}

The mean concentrations of progesterone, LH, FSH and oxytocin in jugular vein samples collected around the time of ovulation are shown in Fig. 1. In conjunction with an examination of the ovaries the blood hormone concentrations showed that 1 ewe was killed during the late luteal phase before the progesterone concentration had fallen, 2 in the follicular phase before the LH surge, 3 during the LH surge, 1 at $25 \mathrm{~h}$ after the start of the $\mathrm{LH}$ surge but before ovulation, 1 at $28 \mathrm{~h}$ after the LH surge and during ovulation and 4 more following ovulation at intervals from 24 to $96 \mathrm{~h}$ after the $\mathrm{LH}$ surge.
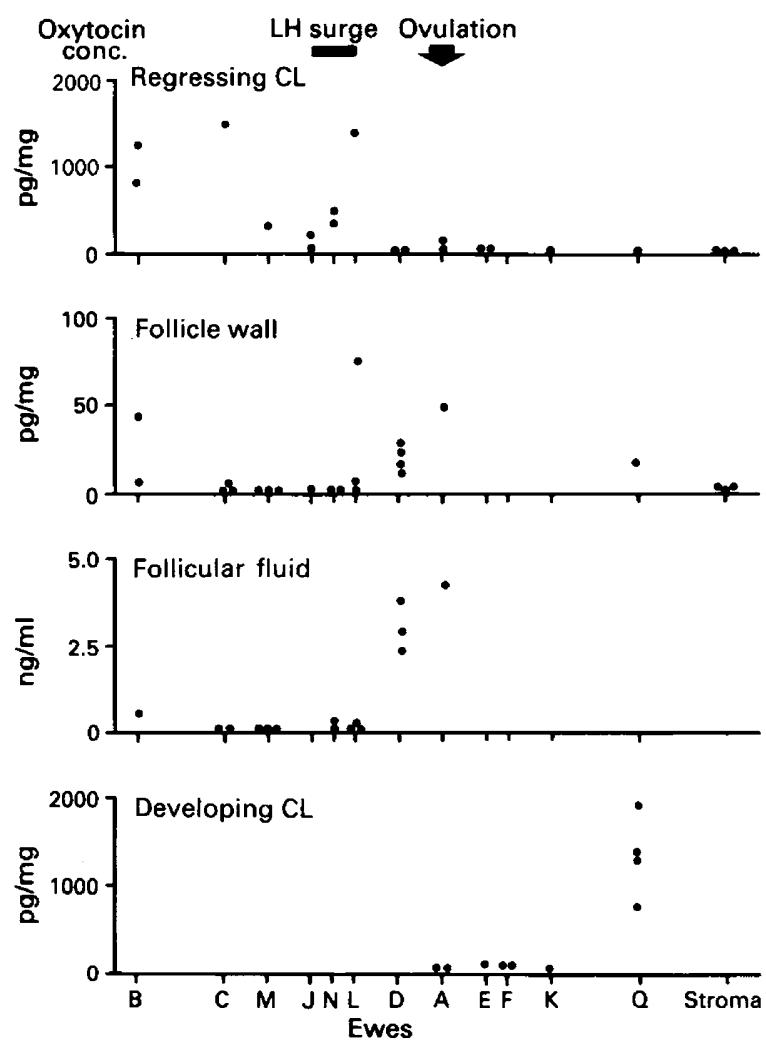

Fig. 2. Concentrations of oxytocin in follicles and corpora lutea collected from the same 12 ewes at various times before and after ovulation. The timing was judged on the basis of the ovarian appearance and the hormonal profile for each animal, and the data from each ewe are arranged in approximate chronological order with reference to the time of ovulation. $\mathrm{B}$, late luteal phase; C, early follicular phase; M, follicular phase just before the LH surge; $L, N \& J$, during the $\mathrm{LH}$ surge; D, $25 \mathrm{~h}$ after the onset of the $\mathrm{LH}$ surge but before ovulation; $\mathrm{A}, 28 \mathrm{~h}$ after onset of LH surge during ovulation; E \& F, 24 and $29 \mathrm{~h}$ after onset of $\mathrm{LH}$ surge just after ovulation; $\mathrm{K}, \sim 13 \mathrm{~h}$ after ovulation; $\mathrm{Q}, \sim 68 \mathrm{~h}$ after ovulation. The concentrations of oxytocin in three samples of ovarian stroma from Ewes C, D and E are also shown. Note the differences in scale for each graph. 
Ovarian oxytocin and vasopressin concentrations

In each of the 12 ewes oxytocin was measured in the corpora lutea and follicles and the results are shown in Fig. 2. In the late luteal phase (Ewe B) and early follicular phase (Ewe C) values in the CL ranged from 823 to $1530 \mathrm{pg} / \mathrm{mg}$ wet weight of tissue whereas in 3 out of 4 ewes concentrations in

Table 2. Vasopressin and oxytocin immunoreactivity concentrations in regressing corpora lutea of sheep

\begin{tabular}{llll}
\hline Ewe & $\quad$ Time of sample collection & $\begin{array}{c}\text { Vasopressin } \\
\text { conc. } \\
(\mathbf{p g} / \mathrm{mg}) \dagger\end{array}$ & $\begin{array}{c}\text { Oxytocin } \\
\text { conc. } \\
(\mathrm{pm} / \mathrm{mg}) \dagger\end{array}$ \\
\hline $\mathrm{B}$ & Late luteal phase & $0 \cdot 8,0 \cdot 7$ & 1282,823 \\
$\mathrm{C}$ & Early follicular phase & $14 \cdot 3$ & 1530 \\
$\mathrm{M}$ & Follicular phase before LH surge & $7 \cdot 7$ & 355 \\
$\mathrm{~J}$ & During LH surge & $1 \cdot 9,7 \cdot 2$ & 249,58 \\
$\mathrm{~N}$ & During LH surge & $4 \cdot 2,5 \cdot 1$ & 474,352 \\
$\mathrm{~L}$ & During LH surge & $6 \cdot 6$ & 1451 \\
$\mathrm{D}$ & Before ovulation, 25 h after LH surge & $\mathrm{ND} \mathrm{ND}$ & 12,8 \\
$\mathrm{~A}$ & During ovulation, 28 h after LH surge & $\mathrm{ND} \mathrm{ND}$ & 117,46 \\
$\mathrm{E}$ & After ovulation, 24 h after LH surge & $1 \cdot 8,1 \cdot 0$ & 69,61 \\
$\mathrm{~K}$ & After ovulation, 41 h after LH surge & $\mathrm{ND}$ & 20 \\
$\mathrm{Q}$ & After ovulation, 96h after LH surge & $\mathrm{ND}$ & 2 \\
\hline
\end{tabular}

$\dagger \mathrm{ND}=$ undetectable $(<17.5 \mathrm{pg}$ per sample). Each value represents the hormone concentration of one corpus luteum.

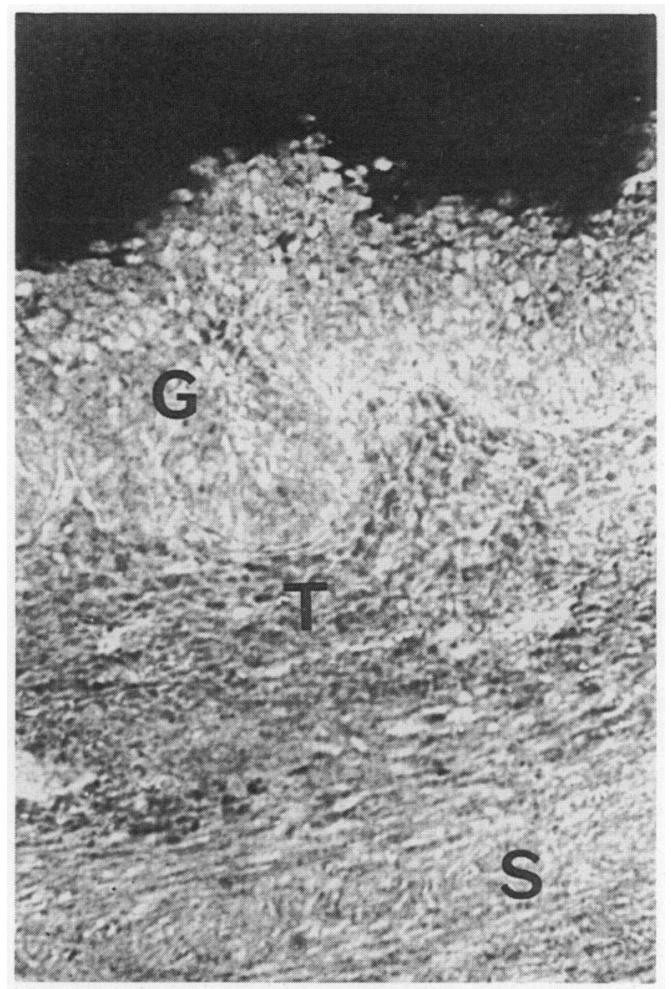

Fig. 3. Section of a follicle taken from Ewe L during the LH surge reacted with anti-oxytocin serum. S, stroma; T, theca; G, granulosa. $\times 200$. 



Fig. 4. Sections of a preovulatory follicle from Ewe D stained with (a) preimmune serum, (b) anti-oxytocin serum and (c) anti-neurophysin serum. Note the presence of immunoreactivity in the granulosa layer $(G)$ but not in the theca layer $(T) . \times 220$.

the regressing CL were $<500 \mathrm{pg} / \mathrm{mg}$ (range $58-473 \mathrm{pg} / \mathrm{mg}$ ) at the time of the LH surge. A still lower range $(8 \cdot 5-117 \mathrm{pg} / \mathrm{mg})$ was found in Ewes D, A, E, and F around the time of ovulation. By Day 4 of the next cycle (Ewe Q) the concentration in the old CL was only $2.4 \mathrm{pg} / \mathrm{mg}$, a value similar to that measured in three samples of ovarian stroma $(3 \cdot 1-4 \cdot 5 \mathrm{pg} / \mathrm{mg})$.

The histological sections of follicle walls showed that these were contaminated with some stromal tissue, and the oxytocin concentrations measured were therefore underestimates. However, they still showed a clear trend. Oxytocin concentrations were no higher than those in the stroma in preovulatory follicles obtained from 2 sheep during the early part of the follicular phase and in 2 of the 3 sheep sampled during the LH surge. In the third (Ewe L), a higher concentration $(79 \mathrm{pg} / \mathrm{mg}$ ) was measured in one $8 \mathrm{~mm}$ follicle, whereas values in two smaller follicles ( 7 and $5 \mathrm{~mm}$ ) were only $6 \cdot 1$ and $7.4 \mathrm{pg} / \mathrm{mg}$. Ewe D was killed just before ovulation and, in this animal, values ranged from 13.3 to $30.9 \mathrm{pg} / \mathrm{mg}$ in 4 follicles of size ranging from 5 to $9 \mathrm{~mm}$. Ewe $A$ had two recent ovulation points and one still unruptured preovulatory follicle which contained $49.4 \mathrm{pg} / \mathrm{mg}$ oxytocin. Detectable values of oxytocin $(20.2$ and $44.5 \mathrm{pg} / \mathrm{mg})$ were also found in two $5.6 \mathrm{~mm}$ follicles from Ewes Q and B which were in the early and late luteal phases respectively, although another follicle of a similar size

Fig. 5. Sections of a follicle just after ovulation from Ewe E stained with (a) anti-oxytocin serum and (b) anti-neurophysin serum. Note the difference in immunoreactivity in the strands of granulosa cells between (a) and (b). $\times 355$. 


from Ewe B contained basal values only. Oxytocin was undetectable $(<155 \mathrm{pg} / \mathrm{ml})$ in follicular fluid from 5 follicles obtained before the LH surge but measured $350 \mathrm{pg} / \mathrm{ml}$ in 1 of the 5 samples collected during the LH surge, and was considerably higher $(2380-4270 \mathrm{pg} / \mathrm{ml})$ in the 4 follicles removed from Ewes D and A just before ovulation.

Concentrations of oxytocin in newly formed CL remained in the range $51-107 \mathrm{pg} / \mathrm{mg}(n=6)$ in the 4 sheep killed $24-41 \mathrm{~h}$ after the LH surge, but had increased to $741-1918 \mathrm{pg} / \mathrm{mg}$ in the 4 corpora lutea from Ewe Q sampled $96 \mathrm{~h}$ after LH.

All samples of ovarian tissue were also analysed for their vasopressin immunoreactivity. Vasopressin was undetectable $(<17.5 \mathrm{pg} / \mathrm{sample})$ in all but one piece of follicle wall, all samples of follicular fluid and all newly formed CL. A small amount $(0.6 \mathrm{pg} / \mathrm{mg})$ was measured in one $8 \mathrm{~mm}$ follicle from Ewe L obtained during the LH surge. However, vasopressin immunoreactivity (range $0.7-14.3 \mathrm{pg} / \mathrm{mg}$ ) was detected in 11 regressing CL obtained from 7 of the 11 ewes samples (see Table 2). This included all animals sampled before the $\mathrm{LH}$ surge, and one $24 \mathrm{~h}$ after.

\section{Immunocytochemistry}

Ovarian tissue samples were taken at representative time intervals throughout the period studied (about 3 days before until 3 days after ovulation). Sections from 16 follicles, 2 mature CL, 4 regressing $C L$ and 10 newly formed $C L$ were examined. No specific staining was observed in any tissue sample with either the pre-immune rabbit serum or the antivasopressin serum (Fig. 4a; Fig.


Fig. 6. Sections of a young corpus luteum ( $\sim 3$ days after ovulation) from Ewe $Q$, stained with (a) anti-oxytocin serum and (b) anti-neurophysin serum. Note that the immunoreactive cells are clustered. $\times 195$. 



Fig. 7. Sections of a mature corpus luteum from Ewe B stained with (a) anti-oxytocin serum and (b) anti-neurophysin serum. Note that the separate cells show identical intensity of staining. $\times 290$.

8b). All samples staining for oxytocin were also positive for neurophysin. No staining for oxytocin or neurophysin was seen in 9 follicles collected before and during the LH surge of which 5 were judged to be preovulatory (Fig. 3). The ovaries of Ewe D ( $25 \mathrm{~h}$ after the start of the LH surge) contained four 5-9 $\mathrm{mm}$ follicles which were extremely vascular and appeared close to ovulating. In these, specific staining for both neurophysin and oxytocin was visible in the granulosa layer, but not in the theca (Figs $4 \mathrm{~b}$ and $4 \mathrm{c}$ ). A further 4 non-ovulatory follicles, collected soon after the time of ovulation, failed to show any specific staining.

In the newly formed CL ( $24-28 \cdot 5 \mathrm{~h}$ after the LH surge, $n=5$ ) there was staining for both oxytocin and neurophysin but this was present only in strands of cells adjacent to the antrum which were derived from the granulosa layer (Figs $5 \mathrm{a} \& 5 \mathrm{~b}$ ). Judging by the intensity of staining, there appeared to be considerably more neurophysin than oxytocin immunoreactivity present in the cells at this time. A similar pattern was seen in one CL obtained $41 \mathrm{~h}$ after the $\mathrm{LH}$ surge. The ovaries of Ewe Q (96 h after LH) contained 4 newly formed CL. In these, oxytocin and neurophysin immunoreactivity were detected in clusters of large luteal cells with an almost equal intensity of staining (Figs $6 \mathrm{a} \& 6 \mathrm{~b}$ ). In a corpus luteum from the late luteal phase (Ewe B) the large luteal cells were unclustered and again showed an equal intensity of staining for both oxytocin and neurophysin (Figs $7 \mathrm{a} \& 7 \mathrm{~b}$ ).

Four regressing CL were examined. Two were obtained just before and during the LH surge; these contained 355 and $1451 \mathrm{pg}$ oxytocin $/ \mathrm{mg}$ respectively and, in each of these, some large luteal cells stained intensely for both oxytocin and neurophysin (Figs 8a \& 8c). One CL obtained $41 \mathrm{~h}$ after 

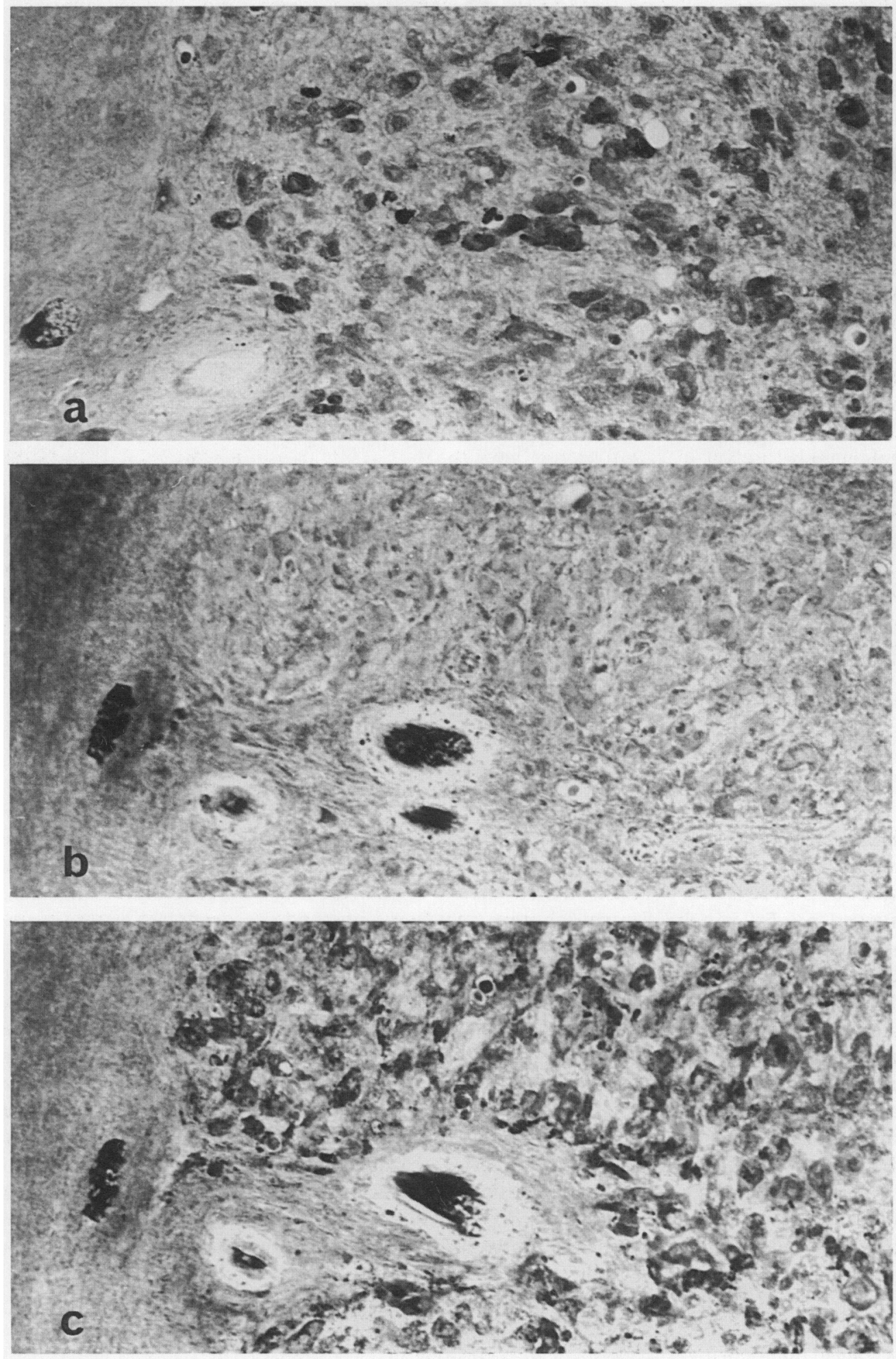
the LH surge contained $20.4 \mathrm{pg}$ oxytocin/mg and in this a few cells were stained for neurophysin and showed faint staining for oxytocin. A CL from Ewe D (immediately before ovulation) contained $8.5 \mathrm{pg}$ oxytocin $/ \mathrm{mg}$ but showed no staining for either oxytocin or neurophysin. Overall there was good correlation between the presence of specific staining for oxytocin and tissue measurements of oxytocin content.

\section{Circulating hormone concentrations}

Mean values are shown in Fig. 1 and three representative profiles in Fig. 9. Progesterone concentrations fell below $0.5 \mathrm{ng} / \mathrm{ml}$ during luteolysis and remained low throughout the follicular phase and immediate post-ovulatory period. The peak value for $\mathrm{LH}$ during the surge was $113.0 \pm 15.7 \mathrm{ng} / \mathrm{ml}(n=9)$ and it lasted for an average of $16.5 \pm 0.50 \mathrm{~h}$ in the 6 ewes for which complete data were available. FSH concentrations increased to a value of $348.3 \pm 46.0 \mathrm{ng} / \mathrm{ml}$ in synchrony with the LH surge; immediately after the LH surge there was a secondary increase in FSH in all 6 ewes monitored. The data were divided into four time periods for analysis of the oxytocin values, and the results are shown in Table 3. An examination of individual profiles showed that release was pulsatile. The largest pulses (up to $120 \mathrm{pg} / \mathrm{ml}$ ) were found in Ewe B during the luteal phase before luteolysis had begun. From the start of luteolysis until the end of the LH surge there was a significant decrease in the mean oxytocin values from $14.6 \pm 6.0$ to $6.0 \pm 0.9 \mathrm{pg} / \mathrm{ml}$ $(P<0.01)$ and this was reflected in the height of the pulses which decreased from $25 \pm 5.8$ to $11 \pm 2.5 \mathrm{pg} / \mathrm{ml}(P>0.05)$. In 5 ewes, for which sampling continued after the LH peak, there was a marked variation in oxytocin values. In three ewes (e.g. Ewe Q, Fig. 9) oxytocin initially remained low $(<10 \mathrm{pg} / \mathrm{ml})$ but in Ewe $\mathrm{Q}$ it increased again about $25 \mathrm{~h}$ after the end of the LH surge. However, in 2 ewes (e.g. Ewe D, Fig. 9) there was an immediate increase in circulating oxytocin concentrations after the $\mathrm{LH}$ surge from $<10$ to about $35 \mathrm{pg} / \mathrm{ml}$. This occurred at the same time as the second rise in FSH concentration but, when all the ewes were considered together, there was no correlation between oxytocin and FSH values in individual samples during this period.

\section{Discussion}

This study shows that oxytocin is first detectable in the preovulatory follicle of the ewe at about the time of the LH surge, and that it is localized in the granulosa cells. During the LH surge a small amount of oxytocin was assayable in the follicle wall and some samples of follicular fluid but, at this stage, neither oxytocin nor neurophysin were found immunocytochemically. However, both types of immunoreactivity were detected in the granulosa layer before ovulation and, immediately after ovulation, the granulosa-derived cells of the newly formed corpus luteum stained intensely with the antineurophysin serum but not so readily with the antioxytocin serum. Within 3 days the oxytocin concentration in the corpus luteum had reached typical mid-cycle levels. A similar study in the cow has also identified the granulosa as the source of ovarian oxytocin. Kruip, Vullings, Schams, Jonis \& Klarenbeek (1985) found immunoreactive staining for oxytocin in the granulosa layer and Schams, Kruip \& Koll (1985) measured immunoreactive oxytocin in bovine follicles and showed that isolated granulosa cells in culture secreted oxytocin into the medium. However, it is still not clear what signal initiates oxytocin synthesis by the granulosa cells.

Previous studies indicate that our antiserum to neurophysin recognizes the common precursor more readily than does our antiserum to oxytocin (Parish, Rodriguez, Birkett \& Pickering, 1981). Therefore, one possible interpretation of the appearance of more intense immunostaining with

Fig. 8. Sections of a regressing corpus luteum from Ewe $M$ stained with (a) anti-oxytocin serum, (b) anti-vasopressin serum and (c) anti-neurophysin serum. $\times 205$. 

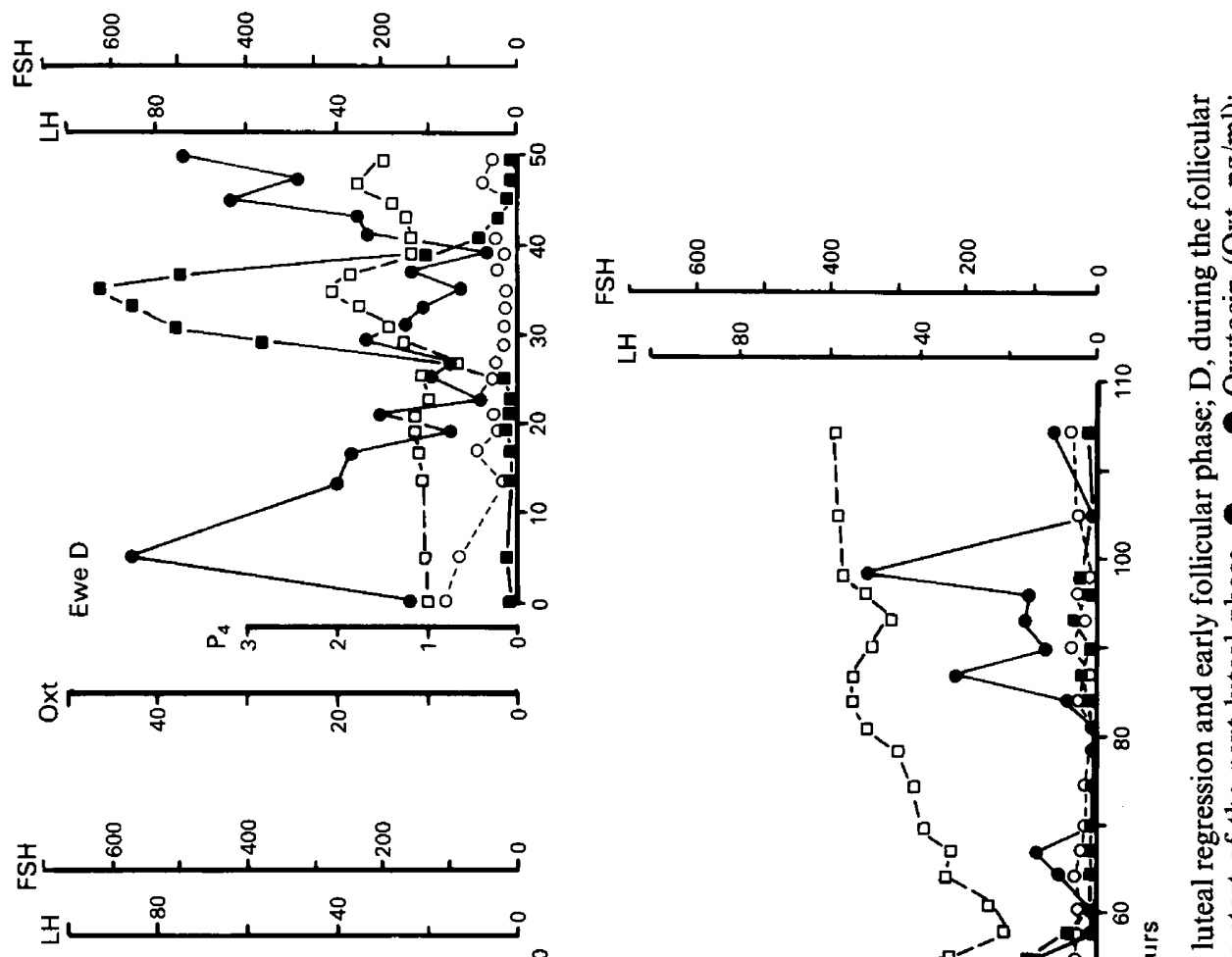

哥全

ษ

를



Ao

递

$\therefore 2$

홇

马

$\bar{\nabla} \Xi$

ᄃ을

密要江

要吅

胥

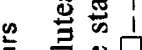
完

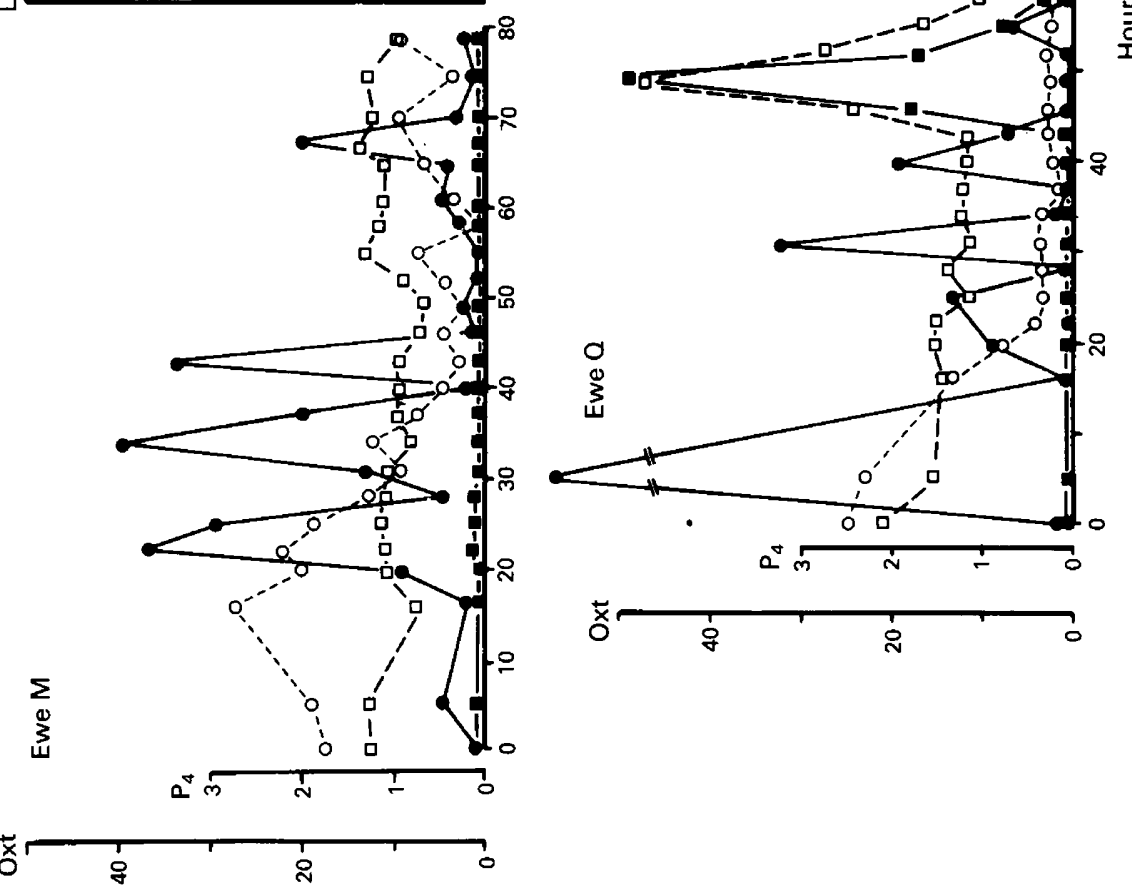

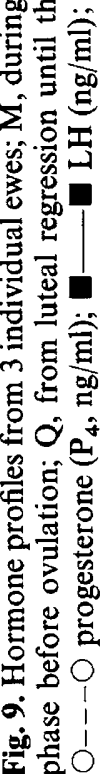


Table 3. An analysis of circulating oxytocin concentrations during the follicular phase of the oestrous cycle of the ewe

\begin{tabular}{|c|c|c|c|c|}
\hline & \multicolumn{4}{|c|}{ Time period* } \\
\hline & Luteolysis $^{\mathbf{a}}$ & $\begin{array}{l}\text { Before LH } \\
\text { surge }^{b}\end{array}$ & $\begin{array}{l}\text { During LH } \\
\text { surge }^{c}\end{array}$ & $\begin{array}{l}\text { After LH } \\
\text { surge }^{d}\end{array}$ \\
\hline No. of ewes sampled & 3 & 10 & 9 & 5 \\
\hline $\begin{array}{l}\text { Oxytocin conc. } \\
(\mathrm{pg} / \mathrm{ml}) \dagger\end{array}$ & $14 \cdot 6 \pm 5.97 \S$ & $10 \cdot 5 \pm 1.178$ & $6.0 \underset{(42)}{0.948}$ & $\frac{9 \cdot 5 \pm 2 \cdot 4}{(23)}$ \\
\hline $\begin{array}{l}\text { Frequency of } \\
\text { oxytocin pulses } \downarrow\end{array}$ & $8 \cdot 0 \mathrm{~h}$ & $11 \cdot 3 \mathrm{~h}$ & $10 \cdot 1 \mathrm{~h}$ & $\begin{array}{c}\text { Insufficient } \\
\text { data }\end{array}$ \\
\hline $\begin{array}{l}\text { Height oxytocin } \\
\text { pulses }(\mathrm{pg} / \mathrm{ml})_{+}^{+}\end{array}$ & $25 \cdot 0 \pm \frac{5 \cdot 85}{(5)}$ & $18 \cdot 4 \pm 2 \cdot 11$ & $11 \cdot 0 \pm \frac{2 \cdot 52}{(7)}$ & $23 \cdot 0 \pm \frac{4 \cdot 11}{(8)}$ \\
\hline
\end{tabular}

antineurophysin than with antioxytocin seen in granulosa cells is that it represents synthesis of the hormone-neurophysin precursor immediately after the LH surge, with full processing to oxytocin only occurring considerably later. Such a suggestion is important because not only does it indicate that some control mechanism may act upon the processing phase of protein and polypeptide secretion, but it also urges caution in the interpretation of increased levels of mRNA in a secretory cell as indicating increased secretory activity in terms of the release of final product.

Our immunocytochemical studies of the preovulatory follicle and young CL demonstrate clearly that oxytocin and neurophysin are localized in the granulosa cells. Initially the stained cells are located in strands, but as the corpus luteum matures these break up to clusters and then to individual cells. This is of particular interest in view of the debate on the origin and fate of the small and large luteal cells in the ewe and cow. It is widely assumed that the granulosa gives rise to the large luteal cells and the theca to the small (O'Shea, Cran \& Hay, 1980). However, other studies have indicated that, although this is true in the initial stages of luteal development, small cells can later develop into large ones (Donaldson \& Hansel, 1966; Fitz, Mayan, Sawyer \& Niswender, 1982). This question has been clarified by Alila \& Hansel (1984) who used specific monoclonal antibodies to cell surface antigens to discriminate between granulosa and thecal cells in the cow. They showed that, as the age of the corpus luteum increases, small theca-derived cells develop into large cells and gradually replace the granulosa-luteal cells. The maximum proportion of granulosaderived large cells (about 75\%) was present on Days 4-6 of the cycle, and by Days 10-12 this figure had declined to about $50 \%$. These data correlate well with our study on the oxytocin content of bovine CL which showed that the highest concentration was present in the first half of the luteal phase and that the tissue oxytocin content dropped significantly before progesterone levels started to fall (Wathes et al., 1984). If the same pattern occurs in the ewe, and only one cell line can make oxytocin, this would explain why oxytocin levels decline at about the same time whether or not the lifespan of the corpus luteum is prolonged by pregnancy or hysterectomy (Sheldrick \& Flint, 1983a, b).

Vasopressin-like immunoreactivity was measured in the majority of regressing CL, but not in the follicles or newly formed CL. There was insufficient material available to perform high-performance liquid chromatography (HPLC) analysis so it is possible that the material was not authentic vasopressin, although our work with cow tissues, based on HPLC and RIA data, suggests that vasopressin is present in the ovary in small amounts (Wathes et al., 1983, 1984). Ivell \& Richter 
(1984) also detected low concentrations of vasopressin mRNA in the bovine corpus luteum. In this species the highest levels were found in the mid-luteal phase (Wathes et al., 1984) which was not examined in the present study. We have been unable to detect the vasopressin-like activity by immunocytochemistry in cows or sheep, so it remains to be determined where it is located and what role it may have.

The pattern of oxytocin secretion during luteolysis which we found was similar to that reported by others for the sheep (Flint \& Sheldrick, 1983) and goat (Homeida \& Cooke, 1983) in that pulses of oxytocin were detected at a time when the peripheral progesterone concentration was declining. It is likely that these pulses are stimulated by the release of PGF- $2 \alpha$ from the uterine endometrium (Flint \& Sheldrick, 1983; Cooke \& Homeida, 1983). In contrast to the general agreement on the pattern of oxytocin release during luteolysis the literature relating to the follicular phase of the ewe is surprisingly disparate. The mean circulating concentration of oxytocin which we measured during this period $(6-10 \mathrm{pg} / \mathrm{ml})$ is similar to that found by Sheldrick \& Flint (1981) and by Webb et al. (1981) who reported levels of $7-10 \mathrm{pg} / \mathrm{ml}$ and $18 \mathrm{pg} / \mathrm{ml}$ respectively. However, Schams et al. (1982) found that oxytocin became undetectable at this time $(<3 \mathrm{pg} / \mathrm{ml})$, whereas Mitchell et al. (1982) reported a mean concentration of about $40 \mathrm{pg} / \mathrm{ml}$. The major pulses of oxytocin appear to have a duration of about $2-3 \mathrm{~h}$, and more frequent sampling (e.g. Mitchell et al., 1982) also revealed fluctuations between minutes. However, the differences between laboratories cannot be explained on the basis of sampling frequency alone. In our study we continued to detect major pulses during the follicular phase of the cycle, although the amplitude declined. As the regressing CL contains appreciable amounts of oxytocin until after the LH surge (see Table 2) it is likely that this is the source of the oxytocin pulses, and that the decreasing height of the pulses reflects the depletion of the luteal store. The rise in circulating oxytocin concentrations in 2 out of 5 ewes immediately after the LH surge is more difficult to explain as there is very little oxytocin present in either the follicles or the corpora lutea at this time, and so the source could be neurohypophysis.

We thank Miss L. Eltringham, Mrs J. Rees, Miss A. Moffatt \& Mr G. Baxter for excellent technical assistance; Mr G. Davies and Mr M. Badman for care of the animals, Dr C. M. Wathes for help with the statistics and the blood sampling; and Mr T. Baker for photography. The work was supported by the M.R.C.

\section{References}

Alila, H.W. \& Hansel, W. (1984) Origin of different cell types in the bovine corpus luteum as characterized by specific monoclonal antibodies. Biol. Reprod. 31, 1015-1025.

Armstrong, D.T. \& Hansel, W. (1959) Alteration of the bovine estrous cycle with oxytocin. J. Dairy Sci. 42, 533-542.

Cooke, R.G. \& Homeida, A.M. (1983) Prevention of the luteolytic action of oxytocin in the goat by inhibition of prostaglandin synthesis. Theriogenology 20, 363365.

Donaldson, L. \& Hansel, W. (1966) Histological study of bovine corpora lutea. J. Dairy Sci. 48, 905-909.

England, B.G., Dahmer, M.K. \& Webb, R. (1981) Relationship between follicular size and antral fluid steroid concentrations at three stages of the estrous cycle in the ewe. Biol. Reprod. 24, 1068-1075.

Fairclough, R.J., Moore, L.G., McGowan, L.T., Peterson, A.J., Smith, J.F., Tervit, H.R. \& Watkins, W.B. (1980) Temporal relationship between plasma concentrations of 13,14-dihydro-15-keto-prostaglandin $\mathrm{F}$ and neurophysin $\mathrm{I} / \mathrm{II}$ around luteolysis in sheep. Prostaglandins 20, 199-208.
Fairclough, R.J., Moore, L.G., Peterson, A.J. \& Watkins, W.B. (1984) Effect of oxytocin on plasma concentrations of 13,14-dihydro-15-keto prostaglandin $F$ and the oxytocin-associated neurophysin during the estrous cycle and early pregnancy in the ewe. Biol. Reprod. 31, 36-43.

Fitz, T.A., Mayan, M.H., Sawyer, H.R. \& Niswender, G.D. (1982) Characterization of two steroidogenic cell types in the ovine corpus luteum. Biol. Reprod. 27, $703-712$.

Flint, A.P.F. \& Sheldrick, E.L. (1983) Evidence for a systemic role for ovarian oxytocin in luteal regression in sheep. J. Reprod. Fert. 67, 215-225.

Guldenaar, S.E.F., Wathes, D.C. \& Pickering, B.T. (1984) Immunocytochemical evidence for the presence of oxytocin and neurophysin in the large cells of the bovine corpus luteum. Cell Tissue Res. 237, 349-352.

Hay, M.F., Cran, D.G. \& Moor, R.M. (1976) Structural changes occurring during atresia in sheep ovarian follicles. Cell Tissue Res. 169, 515-529.

Homeida, A.M. \& Cooke, R.G. (1983) Suppression of pulsatile release of oxytocin during early pregnancy in the goat. Prostaglandins 26, 103-109. 
Ivell, R. \& Richter, D. (1984) The gene for the hypothalamic peptide hormone oxytocin is highly expressed in the bovine corpus luteum: biosynthesis, structure and sequence analysis. $E M B O O J .3,2351-2354$.

Kruip, T.A.M., Vullings, H.G.B., Schams, D., Jonis, J. \& Klarenbeek, A. (1985) Immunocytochemical demonstration of oxytocin in bovine ovarian tissues. Acta endocr., Copenh. 109, 537-542.

Mitchell, M.D., Kraemer, D.L., Brennecke, S.P. \& Webb, R. (1982) Pulsatile release of oxytocin during the estrous cycle, pregnancy and parturition in sheep. Biol. Reprod. 27, 1169-1173.

O'Shea, J.D., Cran, D.G. \& Hay, M.F. (1980) Fate of the theca interna following ovulation in the ewe. Cell Tissue Res. 210, 305-319.

Parish, D.C., Rodriguez, E.M., Birkett, S.D. \& Pickering, B.T. (1981) Effects of small doses of colchicine on the components of the hypothalamo-hypophyseal system in the rat. Cell Tissue Res. 220, 809-827.

Schams, D. (1983) Oxytocin determination by radioimmunoassay. III. Improvement to subpicrogram sensitivity and application to blood levels in cyclic cattle. Acta endocr., Copenh. 103, 180-183.

Schams, D., Lahlou-Kassi, A. \& Glatzel, P. (1982) Oxytocin concentrations in peripheral blood during the oestrous cycle and after ovariectomy in two breeds of sheep with high and low fecundity. J. Endocr. 92, 9-13.

Schams, D., Prokopp, S. \& Barth, D. (1983) The effect of active and passive immunization against oxytocin on ovarian cyclicity in ewes. Acta endocr., Copenh. 103, 337-344.

Schams, D., Kruip, T.A.M. \& Koll, R. (1985) Oxytocin determination in steroid producing tissues and in vitro production in ovarian follicles. Acta endocr., Copenh. 109, 530-536.

Sheldrick, E.L. \& Flint, A.P.F. (1981) Circulating concentrations of oxytocin during the estrous cycle and early pregnancy in sheep. Prostaglandins 22, 631-636.

Sheldrick, E.L. \& Flint, A.P.F. (1983a) Luteal concentrations of oxytocin decline during early pregnancy in the ewe. J. Reprod. Fert. 68, 477-480.
Sheldrick, E.L. \& Flint, A.P.F. (1983b) Regression of the corpora lutea in sheep in response to cloprostenol is not affected by loss of luteal oxytocin after hysterectomy. J. Reprod. Fert. 68, 155-160.

Sheldrick, E.L., Mitchell, M.D. \& Flint, A.P.F. (1980) Delayed luteal regression in ewes immunized against oxytocin. J. Reprod. Fert. 59, 37-42.

Sternberger, L. (1979) Immunocytochemistry, 2nd edn. John Wiley \& Sons, New York.

Swann, R.W., O'Shaughnessy, P.J., Birkett, S.D., Wathes, D.C., Porter, D.G. \& Pickering, B.T. (1984) Biosynthesis of oxytocin in the corpus luteum. FEBS Lett. 174, 262-266.

Wathes, D.C. \& Porter, D.G. (1982) Effect of uterine distension and oestrogen treatment on gap junction formation in the myometrium of the rat. J. Reprod. Fert. 65, 497-505.

Wathes, D.C. \& Swann, R.W. (1982) Is oxytocin an ovarian hormone? Nature, Lond. 297, 225-227.

Wathes, D.C., Swann, R.W., Birkett, S.D., Porter, D.G. \& Pickering, B.T. (1983) Characterization of oxytocin, vasopressin and neurophysin from the bovine corpus luteum. Endocrinology 113, 693-698.

Wathes, D.C., Swann, R.W. \& Pickering, B.T. (1984) Variations in oxytocin, vasopressin and neurophysin concentrations in the bovine ovary during the oestrous cycle and pregnancy. J. Reprod. Fert. 71, 551-557.

Watkins, W.B. (1983) Immunohistochemical localization of neurophysin and oxytocin in sheep corpora lutea. Neuropeptides 4, 51-54.

Webb, R., Mitchell, M.D., Falconer, J. \& Robinson, J.S. (1981) Temporal relationships between peripheral plasma concentrations of oxytocin, progesterone and 13,14-dihydro-15-keto prostaglandin $F$ during the oestrous cycle and early pregnancy in the ewe. Prostaglandins 22, 443-454.

Webb, R., Baxter, G., Preece, R.D., Land, R.B. \& Springbett, A.J. (1985) Control of gonadotrophin release in Scottish Blackface and Finnish Landrace ewes during seasonal anoestrus. J. Reprod. Fert. 73, 369-378.

Received 23 December 1985 